\title{
Study on the Employee Training for China State-owned Enterprises Based on Harmony Concept
}

\author{
Shengming Hou \\ College of Business Administration, North China Electric Power University \\ Beijing 102206, China
}

Tel: 86-10-5196-3675 E-mail: kangwei63@yahoo.cn

\begin{abstract}
The harmonious development of China state-owned enterprise and employees is the essential approach to develop state-owned enterprise. The development of enterprise is the premise of employees' developments, and only harmonious enterprise can ensure employees' complete development and bring up better employees. At the same time, employee's quality decides the development level of enterprise, and employee's survival and complete development are the bases for the harmonious development of enterprise. In this article, we study the employee training for China state-owned enterprises based on harmony concept, and further discuss the harmonious development between enterprise and employees. The contents of the article include the comprehension of harmony concept in the development of China state-owned enterprise, the main contents and the main modes of employee training embodying harmony in the principal of employee training, which can offer primary theoretic base and implementation frame for the work of employee training, and possess the function of reference for the employee training of state-owned enterprise.
\end{abstract}

Keywords: State-owned enterprise, Harmonious development, Employee training, Employee quality

\section{Introduction}

The mutual development of China state-owned enterprise and individual employee embodies the harmony concept, which is the basic approach to enhance employee quality and realize employee value and enterprise value. The development of enterprise is the premise of employee development, and with the quick development of state-owned enterprise, enterprise offers wide stage and plenteous development space to create and realize individual values for employees. The system training that can offer various skills for employees and enhance employees' comprehensive quality is the basic approach for individual development (Cao, Peixi, 2008). The training mechanism can offer more material and spirit returns for employees and make employees be pride because of the rapid development of enterprise and the enhancement of individual value, which can effectively promote the harmony between the whole benefit of enterprise with employees' benefits.

\section{The state-owned enterprise management based on harmony concept}

The harmony concept of state-owned enterprise is to realize the harmony between the quick development of enterprise with the urban development, the harmony between the whole benefit of enterprise with the employee benefit, the harmony between enterprise leader with employees, the harmony among departments of enterprise, and the harmony between the hardware construction of enterprise with the enhancement of employee quality. To realize five objectives of enterprise harmony, enterprise emphasizes the mutual and gradual development between enterprise and employees, establish the harmonious environment of mutual growth of enterprise and employees, and make the harmony embody the development of enterprise and individual at every place.

Through continual and systematically scientific training, every employee in enterprise can be continually enhanced, and not only employees' values can be gradually realized, but also the development of enterprise can be droved. The employee training can inspire employees' potentials and make their ideas open and enhance their own values, and it is the concrete embodiment of people-oriented idea of enterprise, and the impetus to realize the harmonious development of enterprise. At the same time, various training can optimize the study atmosphere in the interior of enterprise, help to establish learning enterprise and organization, and make enterprise realize sustainable harmonious development $(\mathrm{Wu}$, Wei, 2008).

\section{Taking the harmonious development of enterprise as the training objective}

The objective of ability construction for state-owned enterprise is to completely enhance the quality of all employees and form a composite team adapting the demands of new position and new task, accordingly enhance the core competition force of enterprise, and realize quite great developments of enterprise advancement and employee growth. 
To realize this objective, we need acquire breakthroughs from following aspects.

\subsection{The transformation of concept}

The state-owned enterprises of China are still in the key term of historical development, and the interior and exterior environments continually change, and the opportunity and the challenge coexist, which all produce more objectives and requirements for us. The concept is the premise of action, and the implementation of concrete system also carries out the concept. The important objective of quality construction is to transform employees' concepts and open the "shell" restraining employees' ideas (Wang, Jinling, 2008), and make employees accord with the requirements of social and enterprise development from their ideas and consciousnesses.

\subsection{The advancements of individual brand and organizational brand}

The team has brand, and the individual also has his own brand. Only enterprise can establish good enterprise brand, employees can be better trained. With the rapid development and continual grandness of enterprise, enterprise offers wide stage and sufficient development space to create and enhance individual brand for employee. At the same time, only every employee's ability is continually enhanced and his value is gradually realized, he can create harmonious enterprise environment and return enterprise and drive the development of enterprise. Therefore, the individual brand and the organization brand supplement each other and both synchronous enhancements should be realized (Wang, Wenbin, 2008). So the enterprise should try to create the amused work environment and the stage bringing up business, implement employees' occupational layout according to employees' growth demands, implement planned cultivation and actual exercise, inspire employees' potentials, make their ideas open, and accordingly enhance their own values.

\subsection{Developing enterprise and training employees}

State-owned enterprise is the main strength in the national economy. Except for economic responsibility, enterprise also undertakes political responsibility. To keep and increase state-owned assets, ensure investors' benefits and the leading function of state-owned economy to the national economy and the people's livelihood, are all obligatory responsibilities of state-owned enterprise.

Employees are the most precious fortune of state-owned enterprise. Only employees and enterprise grow together, the state-owned enterprise can be developed. And only to continually create more development environments, offer more study and training opportunities, continually enhance employees' welfares and salary treatments, provide more material and spiritual returns, and let employees be pride because of the rapid development of enterprise and the enhancement of individual value can offer powerful impetus for the sustainable development for the state-owned enterprise.

\section{Embodying harmony in the principle of employee training}

\subsection{Paying equal attention to organizational ability and individual ability}

According to the people-oriented strategic deployment to establish harmonious enterprise, the state-owned enterprise should apply itself to enhance employees' various abilities and offer wide development space for employees. When the individual ability is emphasized, the integration of individual ability should also be strengthened and so the team resultant force can be formed for the organization. Employees should not only "study", i.e. increasing their knowledge repertories and enhancing their integrated abilities through classroom training, knowledge competition and special topic discussion, but also "learn", i.e. applying learned knowledge and skills into the work, increasing the whole competition force of enterprise and create real learning organization.

\subsection{Paying equal attention to integrated ability and professional ability}

The professional ability that employees possess to be competent for the post enough is the condition for the survival of enterprise, and the confirmation and enhancement of professional ability is the base for the development of enterprise, so the construction of professional quality ability should be strengthened continually. The urgent position that enterprise reforms system and implements quick development should not only need employees possess familiar and exquisite professional ability, but also need employees develop sustainable and comprehensive integrated abilities. The formation of sustainable competition for enterprise needs composite talents with strong ideas, exquisite operation, high quality and strong ability, so state-owned enterprise should fully develop trainings with multiple layers and angles, so employees' professional ability and comprehensive ability should be enhanced synchronously.

\subsection{Paying equal attention to schooling education and post training}

The state-enterprise should lead employees to implement self-occupational design, support and encourage employees to implement schooling education, strengthen the association with various educational colleges, and offer more possible opportunities for employees to enhance their basic abilities. At the same time, the incumbency educations with multiple orientations and angles such as the post skill training, the expert lecture and the interior central training should be developed to optimize the training project, enhance training quality and enhance employees' professional abilities and skills. So the schooling education and the incumbency education for employees are the base to enhance employees' 
integrated ability and professional ability.

\subsection{Paying equal attention to training efficiency and training mode}

In the construction of ability, the high efficiency of training and the diversity of training mode should be emphasized together. In the design of training, the layer and pertinence should be recognized, and different concrete training projects should be designed aiming at different employees on different posts and different layers to achieve better training effect. The study modes such as classroom lecture, view and visit, group discussion and knowledge competition can enhance employees' theoretical knowledge and practical skills, and the modes such as expert lecture, experience training and foreign view can widen employees' views and let them fully feel the time breath.

\section{Main contents of employee training}

The employee training includes cultivation, education and training for employees in many aspects such as enterprise cultural concept, occupational moral culture, management knowledge, professional technology knowledge, operation skills and work skills according to the requirements of the development plan of state-owned enterprise and the model of employee quality. Its objective is to fully enhance employees' quality and ability, make them better adapt the requirement of post quality ability, and lead them to realize their individual occupational layout objectives in the frame of the whole strategic plan of enterprise (Wang, Xialiang, 2004). The concrete employee training is implemented mainly from five aspects including fresh employee training, professional technology ability training, integrated management ability training, post ability training and culture ability training.

\subsection{Ability training of fresh employee}

The training of fresh employees is the training to make fresh employees can quickly know well the basic situations about the work and the enterprise, such as the strategic perspective, the mission, the core concepts, and the work procedure of the enterprise and relative employee obligation, responsibility, and performance evaluation system.

\subsection{Ability training of professional technology}

The professional technology training includes schooling education and professional technology development training. The schooling training is to acquire higher education level and enhance employees' basic quality level for all employees of the enterprise through adult education, self-study exam or incumbency study. The professional ability development training is to let employees study other professional knowledge, develop their knowledge views and completely enhance their quality and ability.

\subsection{Ability training of integrated management}

The integrated management ability means management knowledge, management skill and individual quality that should be possessed in the management activities or the work process with characters of management. To different posts, the integrated management abilities needed and the corresponding grades of same management ability are different. The training of integrated management ability is implemented aiming at employees on different layers including grass roots employee, general manager, middle-level leader and enterprise leader. The integrated management ability should be constructed from five aspects including self-management ability, professional knowledge ability, security consciousness, communication ability and the ability of exertion, judgment and management.

\subsection{Post ability training}

The post ability construction mainly means the construction of professional quality ability, i.e. the construction of the special professional knowledge and skills needed by special posts or works. The training of professional quality ability is respectively implemented according to different specialties and different layers, and it mainly includes the professional quality ability of human resource, the professional quality ability of client relationship management, the strategic ability, the professional quality ability of finance management, the professional quality ability of security supervision, and the professional quality ability of operation management.

\subsection{Cultural ability training}

The enterprise culture reflects mutual willing, mission and value view of all employees of state-owned enterprise, and it is the reference of value tropism to adapt future development environment and solve enterprise management, the mutual action creed of all employees, the permanent impetus for the sustainable development of state-owned enterprise. The culture ability construction is to make employees continually recognize enterprise culture and strengthen the leading function of enterprise culture to employees through the special topic lecture or the discussion about enterprise culture.

\section{Main modes of employee training}

The main modes of employee training are seen in Table 1 (Yang, 2008).

\section{Conclusions}

The mutual development of China state-owned enterprise and employees embodies the harmony concept, which is the 
basic approach to enhance employee quality and realize employee value and enterprise value. The employee training is a complex engineering, and the specific construction objective and orientation, clear layout and approaches and good relationship among various aspects are all guarantees to realize the anticipated effects of ability construction.

\section{References}

Peixi Cao. (2008). The New Ambit to Exploit the Harmonious Development for State-owned Enterprises. Seeking Truth. No. 5.

Jinling Wang. (2008). Establishing Harmonious State-owned Enterprises in Development and Innovation: Some Considerations about Developing Northeast Old Industrial Base. Theory Horizon. No.2.

Na Wang. (2008). Analysis of China Enterprise Employee Training. Consume Guide. No.1.

Wenbin Wang. (2008). The Promotion of the Harmonious Development for State-owned Enterprises in Northeast China. Journal of Changchun University of Science and Technology (Social Sciences). No.1.

Xialiang Wang, Xiaohua Zhang, Chaorong Hu, Jianhua Yan \& Xiaodong Mo. (2004). Thinking of Employee Training System for China State-owned Enterprises. Neijiang Keji. No.1.

Wei wu. (2008). The Countermeasures and Advices for the Employee Training of State-owned Enterprises. China Economist. No. 6.

Ningsheng Yang, Qinghong Dong \& Xuzhu Chen. (2008). Establishing the Long Efficiency Mechanism of Employee Training. China Power Enterprise Management. No.1.

Jianyou Zhao, Zhenxiang Zhang \& Xudong Wen. (2008). Some Problems Need to Be Clarified in Employee Training. Coal Economic Research. No.1.

Table 1. Modes of employee training

\begin{tabular}{|c|c|c|c|}
\hline \multicolumn{2}{|c|}{ Training mode } & Features & Application range \\
\hline \multirow{3}{*}{$\begin{array}{l}\text { Classroom } \\
\text { training }\end{array}$} & $\begin{array}{l}\text { Schooling } \\
\text { training }\end{array}$ & $\begin{array}{l}\text { The intention of schooling training is to } \\
\text { enhance the group construction of } \\
\text { employees and enhance employees' } \\
\text { basic quality level }\end{array}$ & $\begin{array}{l}\text { Entire employees of state-owned } \\
\text { enterprise }\end{array}$ \\
\hline & Skill training & $\begin{array}{l}\text { Studying other professional knowledge } \\
\text { and developing employees' knowledge } \\
\text { view }\end{array}$ & Employees at the core post \\
\hline & Expert lecture & $\begin{array}{l}\text { Adopting the mode of centralized school } \\
\text { teaching, and employees can accept } \\
\text { much knowledge and low costs in short } \\
\text { time }\end{array}$ & $\begin{array}{l}\text { The training project that the centralized } \\
\text { school teaching can acquire good } \\
\text { effects }\end{array}$ \\
\hline \multirow{4}{*}{$\begin{array}{l}\text { Non-classroom } \\
\text { training }\end{array}$} & $\begin{array}{l}\text { Self-study } \\
\text { exam }\end{array}$ & $\begin{array}{l}\text { Employees study themselves and review } \\
\text { the study effects by the form of exam }\end{array}$ & $\begin{array}{l}\text { The study content is not suitable for the } \\
\text { centralized school teaching, and the } \\
\text { self-study can complete the project }\end{array}$ \\
\hline & Discussion & $\begin{array}{l}\text { Employees discuss or invite relative } \\
\text { experts to communicate front to front }\end{array}$ & $\begin{array}{l}\text { The construction project tying up } \\
\text { practice and needing experience } \\
\text { communication to achieve better } \\
\text { effects }\end{array}$ \\
\hline & Competition & $\begin{array}{l}\text { Mobilizing employees' study enthusiasm } \\
\text { and activity }\end{array}$ & $\begin{array}{l}\text { The project needing comprehension } \\
\text { and memory }\end{array}$ \\
\hline & $\begin{array}{l}\text { Experience } \\
\text { training }\end{array}$ & $\begin{array}{l}\text { Widening views and studying advanced } \\
\text { experiences }\end{array}$ & Middle and high layer managers \\
\hline
\end{tabular}

